\section{Higher education estate data accountability: the contrasting experience of UK and Poland}

Malgorzata Rymarzak, Department of Investment and Real Estate, University of Gdansk

\section{Alexi Marmot, Professor Facility and Environment Management, Bartlett Faculty of the Built}

Environment, UCL

Abstract

Higher education estates are large and valuable assets that affect diverse stakeholders. Despite recent growth, data on university estates has received little concerted attention from national and international statistics bodies. This paper examines and contrasts the evolution of universities and their estates in the UK and Poland, in light of the degree of central government control versus institutional autonomy. Given increased international competition for students, staff and research funding, the paper argues that universities and their stakeholders would benefit from more transparency, the development of an agreed set of estate definitions, standards and regular statistical reports. Data based on agreed standards would provide a basis for comparative analysis and help to run better university estates and facilities, thereby enhancing HEl efficiency, effectiveness and environmental sustainability.

\section{Higher education changes and the idea of a public good}

Universities, with a long and distinguished history since they first appeared in Europe almost one thousand years ago, are now undergoing vast change in their scale, operations, and perceived social and economic importance. Particularly in the last four decades, higher education institutions ${ }^{1}$, HEls, have grown rapidly and are increasingly perceived as vital contributors to the development of the workforce for knowledge-based economies at global, regional, national and local levels. While in 1990, there were fewer than 10.3 thousand HEIs worldwide, the number had almost doubled by 2015 when there were over 18.5 thousand (WHED, 2017), employing over 12.7 million academic staff and educating more than 212 million students (UNESCO, 2017). In 2015, almost 36\% of the global population aged 19 to 24 was enrolled in tertiary education compared to only $14 \%$ in 1990 (World Bank, 2017a). In response to evolving economic needs and social aspirations, higher education systems have moved progressively from being 'elitist' (participation rate below 15 per cent of the age group), to 'mass' (participation of 15-50 per cent), and then to 'universal', accessible to the majority of the age group (Trow, 1973; 2007). Higher education now plays a necessary and increasingly important role in human, economic and social development. It can be viewed as a common good (Marginson, 2016) providing public benefits (McMahon, 2009; Pinheiro et al., 2012; Hancock et al., 2012; Cremonini et al., 2014), while also providing private benefits for university graduates in the form of enhanced employment opportunities and greater lifetime earnings.

The perception of higher education as a public good from which the whole population benefits, has supported state intervention including the belief that the state and its institutions are the best representatives of public interest. Based on this concept, the state has provided the legal framework and funds and was often directly responsible for establishing new universities in line with the needs and values of societal progress. This began to change with the perception that academic institutions should respond to new challenges in the economic and social environment of 'post-industrial' development. Recognition was increasingly given to the importance of multiple stakeholders in higher education including internal stakeholders (students, staff), and external stakeholders (transnational organizations, financing institutions, donors, business interests representing public interest and labour markets) all of whose needs should be taken into consideration in university management (Anderson et al., 2001, 57). The Western model of state intervention in the formation of the welfare state, and an undermining of the Keynesianism paradigm, saw a transition to the 'neo-liberal' paradigm (Marginson, 2011). Inspired by new public management (NPM), many higher education institutions have attempted to reconcile the traditional administration of public sector institutions with management methods borrowed from the private sector. Increasingly they need to compete for public funds with other demands of ageing societies such as health care and pensions. Thus they are driven to seek other sources of finance, including tuition fees from students and external funds for research and consultancy from the private corporate sector. In this model, the state acts in a somewhat passive, supportive role, formulating a policy framework (Goedegebuure et al., 1993; Neave, 2012) and acting as the guardian of the public interest by providing and appraising efficient spending of public funds. 
European higher education systems differ across countries in terms of the role of the state, academic oligarchy and the market (Clark, 1983), and the timing and scope of changes, although they have evolved in a similar direction due to transnational trends (Boli, 1987; Bleiklie, 2007). In an increasing number of countries, direct state control is being replaced by an increased degree of HEl autonomy over their finances, organization, staffing, and academic direction (Estermann et al., 2011, 10). The price to be paid by academic institutions for more self-regulation is increasing accountability to different stakeholder groups (Fumasoli et al., 2014, 6). The higher education sector must demonstrate clearly the value of its teaching and research, and document its productivity and efficiency, in order to convince stakeholders of the value of their investment. Several authors have commented that an 'audit culture' has been established (Shore and Wright, 2015; Strathern, 2000) - also known as an evidence, control or assessment culture (Farkas, 2013) requiring high levels of reporting and transparency of their activities in order to prove their social responsibility. This audit or control culture was imposed initially on higher education institutions by supervisory authorities, particularly government ministries and accreditation agencies. As governments have gradually reduced direct funding to higher education institutions, other financial stakeholders, including third-sector organizations, individual students, and their representative bodies, have promoted the development of accountability metrics and mechanisms (Bogue and Hall, 2003, 224). Higher education institutions need particularly to understand student opinion as one of the important stakeholder groups, constituting the basis for the existence of the education market (UNESCO, 1998, 2). Individual student decisions significantly affect higher education institutions because of the tuition fees or state subsidies that they attract and due to their role as increasingly demanding clients, customers or even partners (Mavondo et al., 2004; Clayson and Haley, 2005; Tight 2013), expecting a positive learning environment in terms of qualified and experienced staff, effective and efficient organization, timetabling, course structure, and capital assets - IT and physical spaces (Kandiko and Mawer, 2013, 9). Despite the importance of physical spaces within higher education institutions (Kuntz et al., 2012), and the need to provide stakeholders with transparent information, little relevant literature analysing HE estates is available. Most real estate studies concentrate on the assets and estate data for commercial corporations.
The aim of this paper is to understand and compare estate data for higher education institutions and consider how they have changed as HEIs and the role of the state in their development have evolved. By focusing on the UK and Poland, countries within Western and Eastern Europe respectively, the evolution of the European higher education systems and institutional autonomy in real estate is discussed for the 25 year period from 1990 to 2015. The range and comparability of information on HEl real estate collected by national statistics offices are presented. The authors conclude with suggested avenues for future action and research to enable the HEl estates to become more efficient, effective, sustainable and supportive of the growing higher education agenda.

\section{UK and Polish higher education in contex}

The UK and Polish higher education systems have been selected as two contrasting examples that are subject to the same transnational changes but have adapted to them differently, due to their different histories, as well as to their contemporary socio-economic situation. The UK has a larger population and is wealthier than Poland, though the wealth gap is closing. Over the past two and a half decades the UK population has grown from 57.2 million in 1990 to 64.8 million in 2015, while the population of Poland has remained almost stagnant at around 38 million. In 1990 the UK GDP/capita was eleven times that of Poland, but by 2015 was just 3.5 times higher (World Bank, 2017b).

The UK higher education system is among the top nine countries in the world in terms of student population. In 1990, it served almost 1.2 million students (EUROSTAT, 1995) and the enrolment rate stood at 26 per cent (World Bank, 2017a), while in 2015 there were more than 2.3 million students (EUROSTAT, 2017a) and the enrolment rate was 56 per cent (World Bank, 2017a). The UK is one of the largest host nations for international students with over 430,000 international students in 2015 (EUROSTAT, 2017b).

In Poland, the system of higher education has significantly expanded over the same 25 year period. As in other post-communist countries of Central and Eastern Europe, rising demand for a larger and better educated workforce since the political changes of 1989 , along with the inability to finance the growth in the number of students from public funds, encouraged the creation of the private sector in higher education thus providing greater accessibility for students. In 1990 the Polish system had 112 state-run HEls, with 
fewer than 0.4 million students and an enrolment rate of approximately 20 per cent (World Bank, 2017a). It has subsequently experienced a truly phenomenal increase in the number of both universities and undergraduates (Kwiek, 2016). In 2015, there were $415 \mathrm{HEIs}$, of which 132 were publicly funded, educating almost 1.7 million students (EUROSTAT, 2017a), primarily domestic - only about 44,000 (3 per cent) were foreign students (EUROSTAT, 2017b). The enrolment rate was 68 per cent of the population aged 19-24 (World Bank, 2017a). In future years, the number of home students is expected to drop in both countries due to a demographic decline in the university age group. Although the drop will be relatively insignificant in the UK, Poland will experience one of the largest drops in Europe, comparable only with the decline in small post-communist countries of Bulgaria, Romania, Slovakia, Estonia, Lithuania and Latvia (Kwiek, 2016).

The systems of the UK and Poland represent different governance models and political priorities for the education sector, grounded in their differing histories. Up until 2015, The UK government limited undergraduate numbers by a government funding grant paid to universities by HEFCE, the Higher Education Funding Council for England and its predecessors (AUDE, 2015). Since 2015, the UK government has had no direct control over undergraduate student numbers, enabling higher education institutions to set their own size, subjects and recruitment objectives. Student tuition fees are paid by the Student Loans Company, an arms-length government body, and repaid by the students after their studies depending on their level of earnings. The evolution towards a more market-oriented system with a focus on 'value for money', stimulated and recommended by the government and institutional administrators, began earlier. In the mid-1980s, the UK government began to emphasize the need to increase efficiency and effectiveness in the management of HEls (Ball and Wilkinson, 1994; Martin and Sauvageot, 2011; Clare, 2012), seen in sections of the Green Paper "The Development of Higher Education into the 1990s" and the 1987 White Paper, "Higher Education: Meeting the Challenge". The pressure for market transparency for taxpayers, 'customers' and other stakeholders, and for improved efficiency of resource allocation, led to the development of metrics and performance indicators as part of the system of monitoring the universities (Harvey and Knight, 1996, 67; Kallio et al., 2017). Transparency and the need for metrics was featured in various publications including the Jarratt Report (Jarratt, 1985), publications by The National Advisory Body for Public Sector Higher Education (NAB, 1987), and publication of annual management statistics for universities (CVCP/UGC, 1987).

In Poland, decisions on the overall number of students were made by the universities themselves, but the government directly provided the funding. In fact, as set out in the Polish Constitution, publicly funded HEls were not permitted to charge tuition fees for full-time studies who were instead to be financed from taxation. Only part-time studies were paid by tuition fees, at a level determined by each HEl. The system is still based primarily on public funding as compared to private financing of education and research. Against the global trend of privatization, the percentage share of students paying tuition in Poland has been decreasing since 2006. Consequently, as Kwiek (2016) correctly observed, there has been de-privatization in higher education, the number of private institutions has decreased, while the number of students whose studies are paid from taxes has grown. Due to the growing share of public funds that finance HEIs, the state has again become one of the most important stakeholders. The universities have been subjected to more direct steering mechanisms and heavy reporting procedures - HEls must submit numerous reports to institutions including the Central Statistical Office of Poland (GUS), the Ministry of Science and Higher Education (MNiSW) and the Ministry of Finance (through the POL-on system). Data from these reports are not fully available to the public.

\section{Estates and the autonomy of HEls}

Increasing pressure on efficiency, effectiveness and sustainability has led HEls to seek new ways to make better use of all resources. In the classical economic sense, according to Adam Smith (1723-1790) and David Ricardo (1772-1823), resources pertain to land, labour and capital. Built wealth excluding land accounts for 70\% of all manufactured wealth, a figure that has declined since the industrial revolution (Pearce, 2003, xi). Since the late 1980s, real estate (defined as both buildings and land), capital, people have been joined by technology and information to create five key resources. In fact, in many institutions, real estate costs including acquisition, construction, maintenance and use, are the second-highest cost after staff salaries (Ibrahim et al., 2012). Despite the importance of real estate as a resource, theories elucidating its value beyond the perspective of its financial return to investors, developers, designers, builders, and operators, 
are in short supply, especially in relation to the management of publicly owned or operated real estate (Muczynski, A, 2015).

Since the establishment of the earliest universities, their real estate has denoted their image and their physical place while offering practical attributes: protection from the weather and providing a setting for teaching and learning, research and associated activities. The physical environment can be important to students when they choose their university, transition to study, and while studying (Marmot, 2014), as confirmed in studies including research carried out by the UK Association of University Directors of Estates (AUDE, 2016) and Higher Education Design Quality Forum (HEDQF, 2013). Well-equipped teaching areas such as classrooms, information and communication technology (ICT) suites, libraries and laboratories are essential for conducting high-quality education and research. Other amenities such as refectories, coffee shops, social learning areas, outdoor spaces and sports facilities also play a role in the health and wellbeing of students. This infrastructure must be adapted to meet changing needs while keeping pace with innovations in teaching and learning (European Commission/EACEA/Eurydice, 2013, 59). To learning theories such as behaviourism, cognitivism, and social constructivism is added a new learning theory, connectivism, responding to the needs of the digital age (Beckers et al., 2015).

Real estate is also important for the staff, who generally spend considerably more time at the university over their years of employment than do students. The physical environment can influence their work performance and productivity and have a significant effect on their behaviour, perception of the institution, and wellbeing. Buildings and land are assets that can add value to the university contributing to growth and change in the university's scale, profitability, productivity, financial sustainability and competitive advantage (Den Heijer, 2011, 101). This is particularly relevant at a time when campuses need to accommodate populations that may be less predictable in size and more diverse in character than previously.

In recent years, both in the UK and Poland, a substantial investment in infrastructure has been made in order to maintain and improve academic and student facilities. In 2015, the total income of the UK higher education sector amounted to $£ 33$ billion with capital expenditure on buildings reaching $£ 3.5$ billion (UCEA, 2017) in creating facilities to accommodate expansion in students, research and consultancy activities
(AUDE, 2015). Many modern and functionally suitable buildings were erected and some older ones were renovated. In addition to the capital investment, another $f 2$ billion was spent annually on the operational costs of university space. The total floor area of university buildings reached almost 22.0 million $\mathrm{m}^{2}$ gross internal area (GIA) (AUDE, 2017), however, the median space per student has slightly reduced in the last few years. In the same year, Poland spent $f 700$ million on public higher education infrastructure (GUS, 2016), and the total floor area was estimated to be around 12 million $\mathrm{m}^{2}$ (POL-on, 2015). The investment upsurge occurred since 2007, when the HEls could finance the development or modernization of their infrastructure from EU funds, particularly Priority 13 (HEI infrastructure, the Infrastructure and Environment Operational Programme). However, changing demographics have led to an increase in space per student in Poland and a deepening problem of inefficient use (Rymarzak, 2016).

The degree of government intervention in HEl real estate varies from country to country. In some European systems HEls are not allowed to own their real estate. Such is the case in Hungary, Serbia and three German states (Brandenburg, Hessen and North Rhine-Westphalia). In other countries, a (semi)public agency owns all HEl buildings, for example, in Austria, Finland and Sweden, higher education institutions are tenants of the public property they use, for which they pay a form of rent (Bennetot Pruvot and Estermann, 2017; EUA, 2017). In Poland and the UK, universities enjoy financial autonomy, although there are considerable differences in its scope. Despite having the legal or formal ability to own buildings, not every country allows HEls autonomously to decide on the sale of their assets. In Poland there are tight restrictions requiring that real estate transactions have the approval of an external authority, the national or local government, that originally provided HEls with the buildings. The UK system normally grants a higher degree of autonomy to its universities on this issue, while requiring accountability.

\section{International and national HE estate data}

Despite the value and importance of HEls and their real estate, data on the estates rarely appears in public statistics. A gap in performance indicators for HEls is noted in Lewis et al. (2007) and Den Heijer and Tzovlas $(2014,21)$. The statistics kept in most countries, as well as Eurostat, fail to present detailed information about HEl buildings. Similarly, organisations like UNESCO, The World Bank and the European 
Commission, that play an increasingly significant role in forming public policy, promoting research directions and exerting expert pressure on national governments or education institutions, do not deal with the issues either. Although each of these bodies annually publishes many papers, analyses and reports on selected aspects of higher education, HEl estates are not included. While OECD does refer to real estate, its work is mostly limited to educational infrastructure and case studies of schools, not universities. Papers published before 2009 in PEB Exchange, the journal of the OECD Programme on Educational Building, are primarily examples of innovative educational building projects, new technologies and trends in educational architecture. Later publications of the OECD Centre for Effective Learning Environments (CELE) mainly focus on the quality of educational facilities (OECD, 2011).

Information on HEl real estate is also ignored in international rankings of universities (such as the Academic Ranking of World Universities - Shanghai Ranking, QS Top Universities, U-Multirank and THS, Times Higher Education), that are increasingly prominent as new accountability tools. These rankings concentrate on aspects such as teaching and learning, research quality, knowledge transfer, international orientation, regional engagement, size and age of the institution, and its legal status, while almost ignoring real estate.

The UK is one country in which the importance of HEI real estate issues has long been recognized through guidance on space and associated capital funds from the University Grants Committee and its successor, HEFCE. In the late 1990s the Association of University Directors of Estates, (AUDE), contributed to the development of the Estate Management Statistics (EMS) in order to provide the UK government and HEls with access to a rich database of information, enabling improved real estate strategy and decisionmaking. Increasing pressure on the transparency of universities to their external environment has meant that, since 2009, the responsibility for publication of EMS has been taken over by the Higher Education Statistics Agency (HESA), the official agency for the collection, analysis, and dissemination of quantitative information on higher education. In response to concerns for environmental sustainability, the last decade has led to a proliferation of new estate metrics for UK university estates on the consumption of energy and water, the generation of $\mathrm{CO}_{2}$ emissions sometimes including by travel on and to the estate, and the generation and recycling of waste, as a precursor to actions for their reduction
Until 2013, the university estate was not of particular interest to the Polish government. HEls were under no obligation to report on the state of their assets and official statistics of the Central Statistical Office of Poland, GUS, made no reference to information on HEl buildings, such as their floor area or financial value. From 2013, HEls could enter data about their real estate into the Integrated System of Information on Higher Education (POL-on), and they have been required to do so only since February 2015.

British and Polish sources of HEl estate information differ significantly, as summarized in Table 1, mainly due to the fact that the information is used for different purposes. In earlier years from 1919, a UK body called the University Grants Commission, UGC, allocated central government funds to universities, both for capital investment and for revenue costs of staff and operations, coordinating and reconciling the plans of each HEl with government policies and financial limits (Shattock, 1984). The UGC included guidance on estate floor area as a means of checking that central government capital grants for university land and buildings were invested wisely and fairly. Subsequently, investment decisions were decentralized, so strict UGC standards of space were eventually supplanted by monitoring each university based on the data the HEls provided. Since 1999, Estate Management Reports, EMR, (formerly referred to as Estate Management Statistics, EMS), have kept 'customers' of higher education and other stakeholders well informed. The reports enable HEI estate administrators to monitor, compare and enhance their HEl's performance, demonstrate added value and communicate with key stakeholders. The EMR covers more than 600 data items for each $\mathrm{HEl}$, including data on student and staff numbers, finance, building floor area, condition and functionality, space management, environment, energy, emissions, and waste (HESA, 2016). All of the data fields have been carefully defined including area measurement. By comparison, POL-on was designed and imposed by the state mainly to help control the higher education system. It is not an estate directors' product, but was originally intended to support the public authority when making decisions on the allocation of public funds. The scope of the data, regulated by the Ministry of Science and Higher Education Ordinance (MNiSW, 2015), covers basic data about buildings, and plots of undeveloped land (such as the registration number of the estate, land register number, the institution's title to the asset, the name of the building, its construction date, data on the space rented to third parties, on the premises and their 
occupancy rate). However, very little information entered by HEls is openly available and parts of the system, such as the finances for individual HEls, are accessible only to ministerial personnel.

Generally, the UK database embraces many more background and estate characteristics, thus enabling multifaceted understanding and analysis of HEl estates. The estate data collected within the POL-on system are less complete. Most Polish HEls have not classified their floor space into the activities for which it is used e.g. teaching, research, while some have not provided any data on their floor area at all. This results in limited possibilities of data comparison and retrospective analysis especially as the POL-on website only contains information for the current academic semester and lacks data on finances, the value of real estate assets, and metrics related to sustainable development. Moreover, there is a lack of detailed definitions and guidance on data entered into the system, which means that, inter alia, the area of buildings can be provided according to two Polish national standards (PN-70/B-02365 or PN-ISO 9836:1997), rendering the collected data non-comparable.

Key challenges in creating estate metrics are the need for precise definition and measurement, and clarity of purpose on the issues that the data are intended to address. Common confusions found in estate metrics are floor area (internal or external measurements; gross, net or room areas); whether only academic space for teaching and research or also student residential space are included; whether space per person should be calculated on headcount or full time equivalent, FTE, and whether just students, or students and staff, should be included as users of the estate. An overarching danger is that data will be used to increase homogeneity by implying that all institutions should have the same average cost or floor area per person, rather than permitting and celebrating variety. UK data from HESA and AUDE indicate that there can be a tenfold difference between the most and least dense universities from about 4 to 40 square metres $\mathrm{GIA} /$ person FTE, depending on whether the HEls are teaching or research intensive, with the national mean hovering around 10 square metres GIA/person FTE.

\section{Future estate data requirements for higher education institutions}

In today's increasingly competitive world, a better understanding of the relationship between university estates and university outcomes is needed if university estates are to be made more efficient and effective.
As for other types of organization, the university estate could and should be viewed as a key strategic resource that contributes to and aligns with - or at least does not hinder - the university's goals (Den Heijer, 2011, 91). The estate's condition, functional suitability, comfort, aesthetics and management have an impact on the staff and students, on the quality of education and research, on how the HEl is perceived locally, nationally and internationally, consequently, on its development potential, and competitive advantage (Marmot, 2014). Estate decisions may also influence the local urban or wider regional economy and stir positive consequences with a beneficial impact on the whole system of higher education and national economy. Estates may provide added value to the university, increase the productivity and satisfaction of different stakeholders, stimulate collaboration and innovation, and contribute to the health and wellbeing of the staff, of the students and the planet.

The estate quantum, cost, asset value, composition, design and functionality should be optimized and allow the HEl flexibility in adjusting to changing conditions, such as the increasing global demand for education and research, continuing innovation in information technology, and increased mobility of students and staff. Demographic changes and the tertiary enrolment rate are also significant challenges, as they affect university demand. Uninformed estate planning may lead to space shortage at times of increasing demand, or to the wasteful allocation of funds to the maintenance of under-used space in times of declining demand.

Decision-makers can be convinced to make informed choices to improve the efficiency and effectiveness of resource allocation if their operations are more transparent. Efforts are needed to improve the quality of university estate data available via public registers. National statistics, deemed an objective and reliable source of information, could enable universities to self-monitor and help to professionalize the HEI management processes, increase competition between HEIs and raise the quality of facilities for education and research. As HEIs are increasingly competing for students, staff, and research funding in a global education market they also need to meet and demonstrate world-class standards of performance. Data comparability between individual HEls within a country, and between countries and regions, is increasingly necessary. 
Over time, estate metrics will be provided more easily. Recent experiments in 'smart cities, and 'smart buildings' provide real time data fed from live sensors, allowing instant adjustment of activities. For example, occupancy sensors provide live information to students on where library seats are available (Valks et al., 2018). In future, existing datasets and estate statistics may be supplemented, improved or replaced by entirely new statistical outputs. The huge potential offered by the 'internet of things' and 'big data' may result in vast, live data streams from digital sensors, that will increase the importance of data and may fundamentally change the way HEls and their estates operate.

Although this paper covers only two countries, it signals a challenge in the lack of agreement on helpful real estate data and its definition. Improved data may reveal and inspire a better understanding of the role of the estate in the higher education planning and management. Though there may be problems of data comparability between nations, there appears to be a case for formulating a set of definitions, based on standards similar to those that exist in other real estate sectors, such as offices (IPMSC, 2014), which in the future may lead to the creation of a single international database. That would be an important tool for HEI leaders in helping to run better university estates and facilities enhancing $\mathrm{HEl}$ efficiency, effectiveness and environmental sustainability. By analysing comparative performance, such data can help HEl policy makers and national governments to measure and then increase the rate of return on national and societal investment in HEls.

\section{Notes}

${ }^{1}$ In this paper we have used the terms 'higher education', 'tertiary education' and 'universities' applying the terms used in the literature cited. In fact there may be occasional differences in the concept of 'postsecondary' or 'tertiary' education that in some countries embraces 'further education' typically covering skilled vocational and technical learning, and 'higher education' covering undergraduate and postgraduate education that is normally delivered by universities.

\section{References}

Anderson, L., Briggs, A. R. J. and Burton, N. (2001) Managing finance, resources and stakeholders in education, London: SAGE Publications Ltd.

AUDE (2015) Higher Education Estates Statistics Report. AUDE Report, 19 November, https://www.aude.ac.uk/resources/news/view?g=7f6f8a92-3d5d-4afc-aca3-e860b68ee928, accessed 10 December 2017.

AUDE (2016) Facilities 'more important' than reputation for university applicants, AUDE, 28 September, https://www.aude.ac.uk/resources/news/view?g=20049673-4673-4c83-a78d-65828072c11e, accessed 15 February 2018

AUDE (2017) AUDE Estates Management Report for 2015/2016 academic year. AUDE Report, 6 October, https://www.aude.ac.uk/resources/news/view?g=0e18bac6-78b5-4837-9be7-bcbdb208b4d4, accessed 15 February 2018

Ball, R. and Wilkinson, R. (1994) 'The use and abuse of performance indicators in UK higher education', Higher Education 27 (4): 417-427.

Beckers, R., Van der Voordt, T., Dewulf, G. (2015) 'A conceptual framework to identify spatial implications of new ways of learning in higher education', Facilities 33 (1/2): 2-19.

Bennetot Pruvot, E. and Estermann, T. (2017) University Autonomy in Europe III. The Scorecard 2017. Brussels, Belgium: European University Association.

Bleiklie, I. (2007) 'Systemic Integration and Macro Steering', Higher Education Policy 20 (4): 391-412.

Bogue, E. G. and Hall, K. B. (2003) Quality and Accountability in Higher Education. Improving Policy, Enhancing Performance, Westport, Conn: Praeger.

Boli, J. (1987) 'World Policy Sources of Expanding State Authority and Organization, 1870-1970', in G. Thomas, J. Meyer, F. Ramirez and J. Boli (eds). Institutional Structure: constituting State, Society and the Individual, Beverly Hills: SAGE, pp. 71-91.

Clare, C. (2012) 'Do Industrial Approaches to Quality Management and Performance Indicators Work for Higher Education?', in G. Bell, J. Warwick and P. Galbraith (eds). Higher Education Management and 
Operational Research Demonstrating New Practices and Metaphors, Rotterdam: Sense Publishers, pp. $31-47$.

Clark, B. R. (1983) The Higher Education System: Academic Organisation in Cross-National Perspective, Berkeley and Los Angeles: University of California Press.

Clayson, D. E. and Haley, D. A. (2005) 'Marketing Models in Education: Students as Customers, Products or Partners', Marketing Education Review 15 (1): 1-10.

Cremonini, L., Westerheijden, D. F., Benneworth, P. and Dauncey, H. (2014) 'In the Shadow of Celebrity? World-Class University Policies and Public Value in Higher Education', Higher Education Policy 27 (3): 341-361

CVCP/UGC (1987) University Management Statistics and Performance Indicators in the UK. London, UK: CVCP/UGC.

Den Heijer, A. (2011) Managing the university campus. Information to support real estate decisions, Delft: Eburon Academic Publishers.

Den Heijer, A., Tzovlas, G. (2014) The European Campus. Heritage and Challenges, Delft: Delft University of Technology.

Estermann, T., Nokkala, T. and Steinel, M. (2011) University autonomy in Europe II. The Scorecard. Brussels, Belgium: European University Association.

EUA (2017) University Autonomy in Europe III. Country Profiles. Brussels, Belgium: European University Association.

European Commission/EACEA/Eurydice (2013) Funding of Education in Europe 2000-2012: The Impact of the Economic Crisis. Luxembourg: Publications Office of the European Union. Eurydice Report.

EUROSTAT (1995) Eurostat Yearbook '95: A Statistical Eye on Europe 1983-1993. Luxembourg: Office for Official Publications of the European Communities.

EUROSTAT (2017a) Number of tertiary education students by level and sex, 2015. Eurostat Statistics
Explained,
30
June,
http://ec.europa.eu/eurostat/statistics-

explained/index.php/File:Number_of_tertiary_education_students_by_level_and_sex,_2015_(thous ands)_YB17.png, accessed 10 December 2017.
EUROSTAT (2017b) Mobile students from abroad enrolled by education level, sex and field of education, 2015. Eurostat, 20 November, http://appsso.eurostat.ec.europa.eu/nui/submitViewTableAction.do, accessed 10 December 2017

Farkas, M. G. (2013) 'Building and sustaining a culture of assessment: best practices for change leadership', Reference Services Review 41 (1): 13-31.

Fumasoli, T., Gornitzka, A. and Maassen, P. (2014) University Autonomy and Organizational Change Dynamics. Oslo: ARENA Centre for European Studies. ARENA Working Paper no. 8.

Goedegebuure, L., Kaiser, F., Maassen, P., Meek, L., Van Vught, F. and De Weert, E. (1993) 'International Perspectives on Trends and Issues in Higher Education Policy', in L. Goedegebuure, F. Kaiser, P. Maassen, L. Meek, F. Van Vught, E. De Weert (eds). Higher Education Policy. An International Comparative Perspective, Oxford: Pergamon Press, pp. 315-348.

GUS (2005) Higher Education Institutions and their Finances in 2004. Warsaw, Poland: Główny Urząd Statystyczny.

GUS (2016) Higher Education Institutions and their Finances in 2015. Warsaw, Poland: Główny Urząd Statystyczny.

Hancock, S., Hughes, G. and Walsh, E. (2012) 'Universities and the Informal Knowledge Economy', in P. Temple (ed). Universities in Knowledge Economy. Higher Education Organisation and Global Change London, New York: Routledge, pp. 118-135.

Harvey, L. and Knight, P. (1996) Transforming Higher Education, Buckingham: Open University Press and Society for Research into Higher Education.

HEDQF (2013) Estates Matter! Report on Survey of Students' views of their universities' estates 2013. London, UK: London School of Economics.

HESA (2016) Estates management record 2015/16. HESA, 20 October, https://www.hesa.ac.uk/collection/c15042, accessed 10 December 2017.

Ibrahim, I., Yusoff, W. Z. W. and Bilal, K. (2012) 'Space Management: A Study on Space Usage Level in Higher Education Institutions', Procedia - Social and Behavioral Sciences 47: 1880-1887. 
IPMSC (2014) International Property Measurement Standards: Office Buildings. IPMSC, November 2014, https://fastedit.files.wordpress.com/2014/11/ipms-office-buildings-november-20141.pdf, accessed 10 December 2017.

Jarratt, A. (1985) Report of the Steering Committee for Efficiency Studies in Universities. London, UK: CVCP. Kallio, K.M., Kallio T. J. and Grossi G. (2017) 'Performance measurement in universities: ambiguities in the use of quality versus quantity in performance indicators', Public Money \& Management 37 (4): 293300

Kandiko, C. B. and Mawer, M. (2013) Student Expectations and Perceptions of Higher Education. London, UK: King's Learning Institute.

Kuntz, A. M., Petrovic, J. E. and Ginocchio, L. (2012) 'A Changing Sense of Place: A Case Study of Academic Culture and the Built Environment', Higher Education Policy 25 (4): 433-451.

Kwiek, M. (2016) 'From Privatization (of the Expansion Era) to De-privatization (of the Contraction Era). A National Counter-Trend in a Global Context', in S. Slaughter and B. J. Taylor (eds). Stratification, Privatization and Employability of Higher Education in the US and EU, Dordrecht: Springer, pp. 311-

Lewis, D. R., Hendell, D. D. and Kallsen, L. (2007) 'Performance Indicators as a Foundation of Institutional Autonomy: Implications for Higher Education Institutions in Europe', Tertiary Education and Management 13 (3): 203-226.

Marginson, S. (2011) 'Imagining the global', in R. King, S. Marginson and R. Naidoo (eds). Handbook on Globalization and Higher Education, Cheltenham: Edward Elgar Publishing Limited, pp. 10-39.

Marginson, S. (2016) Higher Education and the Common Good, Melbourne: Melbourne University Press. Marmot, A. (2014) 'Managing the Campus. Facility Management and Design, the Student Experience and University Effectiveness', in P. Temple (eds). The Physical University. Contours of space and place in higher education, Abingdon: Routledge, pp. 58-71.

Martin, M. and Sauvageot, C. (2011) Constructing an indicator system or scorecard for higher education. A practical guide. Paris, France: International Institute for Educational Planning. UNESCO.
Mavondo, F. T., Sarenko, Y. and Gabbott, M. (2004) 'International and Local Student Satisfaction: Resources and Capabilities Perspectives', Journal of Marketing for Higher Education 14 (1): 41-60.

McMahon, W. W. (2009) Higher Learning, Greater Good: The Private and Social Benefits of Higher Education, Baltimore: The Johns Hopkins University Press.

MNiSW (2015) Rozporzqdzenie Ministra Nauki i Szkolnictwa Wyższego z dnia 29 czerwca 2015 r. w sprawie Systemu Informacji o Nauce (Regulation of the Minister of Science and Higher Education of 29 June 2015 on the Science Information System). Official Journal of Laws of 2015, item 944.

Muczynski, A. (2015) 'An integrated approach to real estate (portfolio) management'. Real Estate Management and Valuation, 23 (2): 5-16

NAB (1987) Management for a purpose: The report of the good management practice group. London, UK: NAB.

Neave, G. (2012) The Evaluative State, Institutional Autonomy and Reengineering Higher Education in Western Europe, Hampshire, England: Palgrave Macmillan.

OECD (2011) Designing for Education. Compendium of Exemplary Educational Facilities 2011. Paris, France: OECD Centre for Effective Learning Environments.

Pearce, D. (2003) The social and economic value of construction, London: nCRISP.

Pinheiro, R., Benneworth, P. and Jones, G. A. (2012) 'Understanding Regions and the Institutionalization of Universities', in R. Pinheiro, P. Benneworth, P. and G. A. Jones (eds). Universities and Regional Development. A Critical Assessment of Tensions and Contradictions, Milton Park: Routledge, pp. 11-32.

$\begin{array}{llll}\text { POL-on } & \text { (2015) Nieruchomości } & \text { (Real } & \text { estate). }\end{array}$

https://polon.nauka.gov.pl/opi/aa/infr/nieruchomosci;jsessionid=2A5053A32BAE835C42FF2D8F4BC 2F237.NwsProdD?execution=e1s1, accessed 10 December 2015.

Rymarzak, M. (2016) 'Autonomia i rozliczalność uczelni w zakresie nieruchomości - przypadek Polski' (Estate autonomy and accountability of higher education institutions: The Polish case), Nauka i Szkolnictwo Wyissze 2 (48): 119-137.

Shattock, M. and Berdahl, R. (1984) 'The British University Grants Committee 1919-83: Changing relationships with government and the universities', Higher Education 13 (5): 471-499. 
Shore, C. and Wright, S. (2015) 'Audit Culture Revisited. Rankings, Ratings, and the Reassembling of Society', Current Anthropology 56 (3): 1-10.

Strathern, M. (ed.) (2000) Audit Cultures. Anthropological studies in accountability, ethics and the academy, London and New York: Routledge.

Tight, M. (2013) 'Students: Customers, Clients or Pawns?', Higher Education Policy 26 (3): 291-307.

Trow, M. (1973) Problems in the Transition from Elite to Mass Higher Education, Berkeley: Carnegie Commission on Higher Education.

Trow, M. (2007) 'Reflections on the transition from elite to mass to universal access: Forms and phases of higher education in modern societies since WWII', in J. J. F. Forest and P. G. Altbach (eds). International Handbook of Higher Education, Dordrecht: Springer, pp. 243-280.

UCEA (2017) Income and Expenditure in Higher Education. UCEA, 18 July, http://www.ucea.ac.uk/download.cfm/docid/116E55D0-7EE4-4E85-9ABE1A659F76C925, accessed 10 December 2017.

UNESCO (1998) World declaration on higher education in the twenty-first century: Vision and action. Paris, France: UNESCO.

UNESCO (2017) Education. UNESCO, http://data.uis.unesco.org/, accessed 10 December 2017.

Valks, B., Arkesteijn, M. H., Den Heijer, A. C., Vande Putte, H. J.M. (2018) 'Smart campus tools - adding value to the university campus by measuring space use real-time', Journal of Corporate Real Estate 20 (2): 103-116

WHED (2017) Worldwide Database of Higher Education Institutions. WHED, http://whed.net/About.html, accessed 10 December 2017.

World Bank (2017a) Gross enrolment ratio, tertiary, both sexes. World Bank,

https://data.worldbank.org/indicator/SE.TER.ENRR?end=2015\&start=1990, accessed 10 December 2017.

World Bank (2017b) GDP per capita. World Bank,

https://data.worldbank.org/indicator/NY.GDP.PCAP.CD?end=2015\&start=1990, accessed 10

December 2017 